\title{
Blue-stain fungi associated with Tomicus piniperda in Sweden and preliminary observations on their pathogenicity
}

\author{
H Solheim ${ }^{1^{*}}$, B Långström 2 \\ 1 Norwegian Forest Research Institute, Section of Forest Ecology, \\ Division of Forest Pathology, PO Box 61, N-1432 As-NLH, Norway; \\ 2 Swedish University of Agricultural Sciences, Division of Forest Entomology, \\ S-770 73 Garpenberg, Sweden
}

(Received 9 July 1990; accepted 13 November 1990)

\begin{abstract}
Summary - Mass attacks by Tomicus piniperda were induced in young Scots pines of varying vitality by baiting the trees with split, fresh pine bolts. Trees were felled at different times to determine the development of blue-staining of sapwood. Fungi were isolated from samples of inner bark and blue-stained sapwood in connection with galleries of $T$ piniperda. Samples were also taken from beetle-attacked pine timber. In addition, 4 stem-pruned trees were inoculated with the 2 most important species isolated from trees attacked by $T$ piniperda. Three species of fungi were rather frequently isolated, Hormonema dematioides, Leptographium wingfieldii and Ophiostoma minus. The latter 2 species were most active in invading the sapwood. Blue-staining of sapwood occurred rather late in the season, 1-2 months after attack. One tree in each pair of trees inoculated with $L$ wingfieldii and $O$ minus were dying when harvested more than 4 months after mass inoculation. Thus, these fungi may play a role in overcoming the resistance of trees under beetle attack.
\end{abstract}

blue-stain fungi / Tomicus piniperda / Pinus sylvestris / insect-fungus relationship / pathogenicity

Résumé - Champignons du bleuissement associés à Tomicus piniperda en Suède et observatlons préliminaires sur leur pathogénlclté. Des attaques massives de Tomicus piniperda ont été provoquées sur des jeunes pins sylvestres de vitalité variée, en appátant les insectes avec des fragments de rondins de pin frais. Les arbres ont été abattus à différentes dates pour suivre le développement des champignons du bleuissement dans l'aubier. Les champignons ont été isolés à partir d'échantillons d'écorce inteme et d'aubier bleui, situés en correspondance avec des galeries de Tomicus piniperda. Des échantillons ont aussi été prélevés sur des grumes attaquées. De plus, 4 arbres complètement élagués ont été inoculés avec les 2 plus importantes espéces précédemment isolées des arbres attaqués par T piniperda. Trois espèces de champignons ont été assez fréquemment isolées, Hormonema dematioides, Leptographium wingfieldii, et Ophiostoma minus. Les 2 dernières nommées se sont avérées les plus actives à envahir l'aubier. Le bleuissement de l'aubier est intervenu plutôt tardivement, 1 à 2 mois après l'attaque. L wingfieldii et $O$ minus ont tué au moins un arbre chacun après inoculations massives. Il est donc possible que ces champignons jouent un róle pour vaincre les arbres attaqués par les Scolytes.

champignon du bleulssement / Tomicus piniperda / Pinus sylvestris / relation insectechamplgnon / pathogenicité

\footnotetext{
* Correspondence and reprints
} 


\section{INTRODUCTION}

Many bark beetles attacking conifers are associated with blue-stain fungi, which play a key-role in success or failure of beetle establishment. This has been shown for several bark beetle-fungus associations, eg the Eurasian spruce bark beetle Ips typographus (L) and the blue-stain fungus Ophiostoma polonicum Siem (Horntvedt et al, 1983; Christiansen and Horntvedt, 1983; Christiansen, 1985; Solheim, 1988).

Some of the bark beetles associated with Scots pine (Pinus sylvestris $L$ ) have long been known to carry blue-stain fungi (Rennerfelt, 1950; Mathiesen-Käärik, 1953; Francke-Grosmann, 1967). These had not been considered pathogenic until a beetle outbreak in Central France caused considerable mortality in Scots pine, and the interactions between fungi and beetles came into focus (Lieutier et al, 1988). A complex of 2 bark beetles, Tomicus piniperda (L) and Ips sexdentatus (Börn) and associated blue-stain fungi has been held responsible for the pine mortality in France, stress and low tree vitality probably being important predisposing factors (Lieutier et al, 1989; Piou and Lieutier, 1989).

In Sweden, Scots pines were found to produce distinct reaction zones in response to induced stem attacks by $T$ piniperda, and fungi were apparently present in the sapwood of successfully colonized trees (Långström and Hellqvist, 1988). This finding initiated a series of experiments to clarify the defensive system of Scots pine against bark beetles and their possible fungal associates. In the present paper, we report on the species of fungi found in association with $T$ piniperda in Sweden, including some remarks on their ecology and pathogenicity.

\section{MATERIAL AND METHODS}

\section{Study areas}

Field work was conducted in 2 study areas in the province of Gastrikland in Central Sweden (= $61^{\circ} \mathrm{N}$ lat, $16^{\circ} \mathrm{E}$ long). One site was situated on a pine-covered moraine at Norrsundet close to the Baltic sea, and the other on a dry pine heath at Jädraås ( $\approx 185 \mathrm{~m}$ above sea level). Both sites were pure pine stands, $\approx 35$ and $25 \mathrm{yr}$ old, and stocked with $\approx 2500$ and 1000 stems per hectare, respectively. Tree diameter range was 5-8 $\mathrm{cm}$ (including bark) at Norrsundet, and 4-5 cm at Jädraås. Some of the trees at Norrsundet were heavily damaged by shoot-feeding of Tomicus beetles, originating from the timber store of an adjacent pulp mill. The stands at Jädraås were free of any visible beetle damage.

\section{Isolation of fungi}

In 1988, attacks by $T$ piniperda at Norrsundet were induced in 88 young Scots pine trees, representing 4 different vigour classes, by attaching split pine bolts to the stem. The vigour classes were as follows: unpruned trees in good condition; unpruned trees with reduced crown due to previous shoot-feeding by Tomicus beetles; similar beetle-damaged trees pruned (from below) to 50 and $25 \%$ crown length, respectively. The trees were pruned on 30 March 1988, $\approx 1$ wk prior to beetle flight and attack. Beetle attacks were induced in trees by attaching a split bolt of fresh pine timber to the stem. The attack pattern of the beetles as well as the defence reactions of the trees were similar to those reported by Långström and Hellqvist (1988), and will be reported in detail elsewhere (Långström et al, submitted).

From April to September 1988, a total of 60 trees were felled on 5 occasions (table III) (the remaining 28 trees were felled in August 1989). The upper and lower ends of sample bolts taken from the felled trees (cut at 0.3, 0.8, 1.3 and 1.8 $\mathrm{m}$ stem height), were visually checked for the occurrence of blue-stain. If present, the stained percentage of the cross-sectional area was estimated. 
At the felling carried out on 6 September 1988 , stem sections between $1.0-1.3 \mathrm{~m}$ stem height were taken for isolation of fungi. Isolations were made in blue-stained wood inside galleries of $T$ piniperda, $0.5,1.5,2.5$ and $3.5 \mathrm{~cm}$ inside the cambium. Small pieces of wood, 5-10 $\mathrm{mm}^{3}$, were taken aseptically, placed on plates with malt agar ( $2 \%$ malt, $1.5 \%$ agar) and incubated at room temperature in darkness.

In 1989, beetle attacks were again induced in pine trees of different vigour and pruning history in the low-vigour stand at Norrsundet. Three sets of 20 similar-looking trees had previously been pruned to $\approx 40 \%$ crown length on 21 June 1988, 9 September 1988 and 9 March 1989, respectively. On 20 March 1989, half of these trees were baited with split pine bolts in order to attract more beetles to attack these trees than the pruned but unbaited ones. In addition, 72 unpruned trees, representing the full range in tree size in the stand, were selected and baited.

Ten trees (ie, 5 baited and 5 unbaited) from each pruning group were felled in June and in August 1989. In addition, unpruned trees were felled in August and October (table III). Bluestained sapwood was estimated as in the previous year. Stem sections between $80-130 \mathrm{~cm}$ in stem height were taken for fungal isolations in June and August.

At Jädraås, stem-pruned pines (intended for a caging experiment) were spontaneously and unintentionally attacked by $T$ piniperda in the spring of 1989. Nine of these attacked trees were felled on 2 and 13 June, and stem sections were taken for fungal isolations.

On 2 june, fungal samples were also taken from a pile of logs at Jädraås, $\approx 200 \mathrm{~m}$ away from the attacked standing trees.

From all samples taken in June, fungi were isolated in the phloem reaction zone around galleries, and 1 and $3 \mathrm{~mm}$ inside the wood beneath galleries. From samples taken in August, isolations were made from blue-stained sapwood as in the previous year. Mostly 4 or 5 galleries were chosen for isolations from each tree or log.

\section{Inoculation experiment}

On 2 June 1989, 4 stem-pruned pine trees at Jädraås were inoculated with cultures of Leptographium wingfieldii Morelet and Ophiostoma minus (Hedgc) $\mathrm{H}$ et $\mathrm{P}$ Syd. Two of the trees had been pruned on 2 September 1988, and the others on 24 May 1989, in both cases up to and including whorl 1985 . One tree of each pruning class was inoculated with each fungus. All 4 trees had escaped beetle-attack in spring 1989.

The inoculations were made with a $5-\mathrm{mm}$ cork borer in 6 rings encircling the stem $10 \mathrm{~cm}$ apart from each other (Solheim, 1988). Each ring consisted of 5-6 inoculations, set $2 \mathrm{~cm}$ apart. Each tree thus received $30-36$ inoculations over a $50-\mathrm{cm}$ section from $1.2-1.7 \mathrm{~m}$ stem height, corresponding to a density of 600 per $\mathrm{m}^{2}$.

The fungal cultures originated from previous samples from trees attacked at Norrsundet in 1988 , and were grown on standard malt agar medium.

The trees were felled on 17 October 1989 , taken to the laboratory, and immediately placed in buckets with a water suspension of Fast Green ( $0.25 \mathrm{~g}$ in $1 \mathrm{I}$ water) in order to check the water conducting capacity of the sapwood (see also Parmeter et al, 1989).

\section{RESULTS}

\section{Fungal flora}

Three species of blue-stain fungi were often isolated in association with galleries of $T$ piniperda in June. (The mean attack density on these trees was generally high, ranging from $150-400$ galleries per $\mathrm{m}^{2}$.) These fungi were Hormonema dematioides Lagerb et Melin, Leptographium wingfieldii and Ophistoma minus. The frequency of their association was rather variable (table I). $L$ wingfieldii and $O$ minus were never isolated around the same galleries. $H$ dematioides frequently occurred together with the 2 others. All 3 were mostly isolated only from reaction zones in the bark, even though $L$ wingfieldii was also isolated from sapwood on about half the occasions. Ophiostoma piceae (Münch) H et $P$ Syd and $O$ pilifera $(F r) H$ et $P$ Syd 
Table I. Frequency of fungi isolated in association with galleries of $T$ piniperda in June 1989 from standing trees or logs.

\begin{tabular}{lccccc}
\hline & $\begin{array}{c}\text { No of } \\
\text { galleries/trees }\end{array}$ & $\begin{array}{c}\text { H dematioides } \\
(\%)\end{array}$ & $\begin{array}{c}\text { L wingfieldii } \\
(\%)\end{array}$ & $\begin{array}{c}\text { O minus } \\
(\%)\end{array}$ & $\begin{array}{c}\text { Ophiostoma spp } \\
(\%)\end{array}$ \\
\hline Norrsundet, trees & $107 / 15$ & 1 & 9 & 8 & 3 \\
Jädraås, trees & $44 / 9$ & 44 & 16 & 30 & 5 \\
Jädraăs, logs & $30 / 6$ & 5 & 0 & 10 & 0 \\
\hline
\end{tabular}

were isolated a few times. In addition, yeasts, bacteria, different sterile mycelia and some species of Sphaeropsidales were isolated.

Isolations from the wood in autumn, after blue-stain had developed, showed that $L$ wingfieldii and $O$ minus caused most of the staining (table II). $H$ dematioides, $O$ europhioides (Wright et Cain) H Solheim, $O$ piceae and $O$ pilifera were also isolated, but always together with one of the 2 others. At this time, however, it was rather difficult to determine from which gallery the blue-staining had spread.

\section{Blue-staining}

Visible sapwood blue-stain developed slowly and only in a few trees (table III). In both years, only minor patches of bluestain were seen in a few of the trees felled in May/June, whereas extensive bluestaining occurred in successfully attacked trees felled in August/September.

In 1988, blue-stain in sapwood was observed only in 5 of the severely pruned trees. In the following year, 4 pruned trees of each pruning date displayed blue-stain at felling, whereas 8 of the 32 unpruned trees were stained.

\section{Pathogenicity}

At harvest on 17 October 1989, 3 of the 4 inoculated trees were green and looked healthy, whereas the fourth was yellowish and in poor condition. The Fast Green test, however, revealed that none of the trees had normal water uptake and 2 of them were apparently dying, since $80-90 \%$ of the sapwood was non-conducting. Both dying trees had been pruned in Mayy 1989,

Table II. Frequency of fungi isolated in blue-stained sapwood under galleries of $T$ piniperda in autumn 1988 and 1989 at Norrsundet.

\begin{tabular}{cccccc}
\hline $\begin{array}{c}\text { No of } \\
\text { galleries/trees }\end{array}$ & $\begin{array}{c}\text { H dematioides } \\
(\%)\end{array}$ & $\begin{array}{c}\text { L wingfieldii } \\
(\%)\end{array}$ & $\begin{array}{c}\text { O minus } \\
(\%)\end{array}$ & $\begin{array}{c}\text { Ophiostoma spp } \\
(\%)\end{array}$ \\
\hline 1988 & $21 / 3$ & 0 & 90 & 62 & 19 \\
1989 & $48 / 12$ & 2 & 71 & 46 & 10 \\
\hline
\end{tabular}


Table III. Blue-stain at $30 \mathrm{~cm}$ height of stempruned and unpruned trees attacked by $T$ piniperda and felled during 1988 and 1989 at Norrstundet.

\begin{tabular}{cccc}
$\begin{array}{c}\text { Date of } \\
\text { felling }\end{array}$ & $\begin{array}{c}\text { No of } \\
\text { stained } \\
\text { trees }\end{array}$ & $\begin{array}{c}\text { Mean \% of } \\
\text { stained } \\
\text { sapwood }\end{array}$ & $\begin{array}{c}\text { Total No } \\
\text { of trees }\end{array}$ \\
\hline
\end{tabular}

$\begin{array}{llrr}1988 & & & \\ 20 \text { April } & 0 & - & 12^{a} \\ 4 \text { May } & 0 & - & 12^{a} \\ 24 \text { May } & 1 & 12^{a} \\ 21 \text { June } & 1 & 45 & 12^{a} \\ 6 \text { sept } & 3 & & 12^{a}\end{array}$

1989

\begin{tabular}{rrrr}
1 June & 1 & 6 & $30^{\mathrm{b}}$ \\
24 Aug & 11 & 67 & $30^{\mathrm{b}}$ \\
24 Aug & 2 & 71 & $15^{\mathrm{c}}$ \\
17 oct & 6 & 83 & $17^{\mathrm{c}}$ \\
\hline
\end{tabular}

a Includes 3 trees of each of four vigour classes.

b Pruned trees, 10 trees of each of 3 pruning dates. Unpruned trees.

and one of the dying trees was inoculated with $L$ wingfieldii (the yellowish tree mentioned above), and the other with $O$ minus.

\section{DISCUSSION}

Although our material was limited, it seems that $H$ dematioides, $L$ wingfieldii and $O \mathrm{mi}$ nus are associated with $T$ piniperda in Sweden. The frequency of the fungi in the galleries seems to be low and rather variable. We did not attempt to isolate fungi from the beetles. Previously, the same species have been demonstrated to occur together with $T$ piniperda in France, where the fungi have been isolated both from beetles and galleries (Lieutier et al, 1989; Piou and Lieutier, 1989). The association with $H$ dematioides is high and uniform; with $L$ wingfieldii it is low and uniform and with $O$ minus very variable (Lieutier et al, 1989).

The first record of blue-stain fungi associated with $T$ piniperda was made by MacCallum (1922) in Scotland, who found $O$ minus and $O$ piceae there. In Germany, Grosmann (1931) mentioned $O$ minus and $H$ dematioides. Siemaszko (1939) found $O$ minus as a constant component in Poland, and other species more sporadically, eg $O$ piceae, $O$ pilifera and Aureobasidium pullulans (de Bary) Arnaud. Studies in Sweden have paid special attention to $O$ minus and $A$ pullulans, but many other species have been found in connection with attack of $T$ piniperda (Mathiesen, 1950; Rennerfelt, 1950; Mathiesen-Käärik, 1953).

Most of the species mentioned in association with $T$ piniperda are also isolated in connection with other bark beetles, especially species attacking pines. $O$ minus, which is always mentioned together with $T$ piniperda, is associated with different bark beetles both in Europe and North America (Käärik, 1980; Upadhyay, 1981).

Since $H$ dematioides has been synonymized with $A$ pullulans (Robak, 1932), and then again considered a distinct species (Roback, 1952; Butin, 1963; HermanidesNijhof, 1977), these 2 species have often been confused. Today it is impossible to know which species the different authors may have meant, since no cultures are available. Records on $A$ pullulans associated with $T$ piniperda in Poland (Siemaszko, 1939) and Sweden (Mathiesen, 1950; Rennerfelt, 1950; Mathiesen-Käärik, 1953) may thus in fact refer to $H$ dematioides.

$L$ wingfieldii is a recently described species (Morelet, 1988). Earlier this species may have been included in another Leptographium species, eg $L$ lundbergii Lager et Melin, found in association with $T$ piniper- 
$\mathrm{da}$ and other bark beetles in Sweden (Mathiesen, 1950).

Our data show that $L$ wingfieldii and $O$ minus were the most important invaders of sapwood, and that the former species occurred more frequently than the latter. In contrast, Lieutier et al (1989) found $O \mathrm{mi}$ nus more frequently than $L$ wingfieldii in galleries of $T$ piniperda as well as in sapwood inside the galleries.

In studies using single inoculations, both $L$ wingfieldii and $O$ minus produced long reaction zones and long fungal extensions in the bark, longest in the case of $L$ wingfieldii (Lieutier et al, 1988, 1989). In contrast, $H$ dematioides yielded short reaction zones and hardly any fungal extension (Lieutier et al, 1988, 1989). Thus, Lieutier et al (1989) concluded that despite its low frequency in beetle galleries, $L$ wingfieldii may play an important role in the treekilling process due to its high aggressivity to Scots pine and uniform occurrence with $T$ piniperda. As regards $O$ minus, the association with $T$ piniperda was variable and fortuitous, but $O$ minus may still be involved in the tree-killing process (Lieutier et al, 1989). In North America, O minus has repeatedly been shown to be capable of killing seedlings, saplings and older trees (Nelson and Beal, 1929; Nelson, 1934; Caird, 1935; Bramble and Holst, 1940; Mathre, 1964; Basham, 1970; Owen et al, 1987).

In our pilot study, both $L$ wingfieldii and $O$ minus seem to be able to kill trees when mass inoculated. The dose used was rather high, 600 inoculations per $\mathrm{m}^{2}$ within a $50-\mathrm{cm}$ belt, but comparable to the inoculum dose needed to kill healthy spruce trees with $O$ polonicum (Christiansen, 1985). No control inoculations were carried out, but compared with mass inoculation of $O$ polonicum in Scots pine (Christiansen and Solheim, 1990) its seems that a control inoculation will not affect the trees much. The pruning itself would not have killed the trees, as indicated by the fact that all trees pruned in 1988 were still alive at the time of inoculation. In a similar study in the same areas, Långström and Hellqvist (1988) demonstrated that trees pruned in a similar way in autumn and spring did not differ in resistance to beetle attacks. Furthermore, they found that even severely pruned trees survived despite heavy beetle attack. Thus, it is reasonable to assume that the 2 dying trees in the present study were killed by the mass inoculation.

In laboratory tests $L$ wingfieldii has been shown to grow faster than $O$ minus at low temperatures (Lieutier and Yart, 1989), and since the beetles attack early in the season (early and late April in 1988 and 1989 , respectively in the study area), $L$ wingfieldii may be better adapted to the conditions prevailing during the attack than $O$ minus. In trees, however, Lieutier et al (1990) could not explain all the differences in kinetics of growth between fungi and between seasons by temperature and defence reaction alone; other factors might interfere.

Despite the early date of attack, the first signs of blue-stain development were not seen until 1-2 months later. This may be due to low temperature inhibiting fungal growth and high tree resistance in spring. Horntvedt (1988) found in a seasonal inoculation study with $O$ polonicum on Norway spruce (Picea abies L) that temperature had a great influence on blue-stain development in sapwood, but in spring and early summer tree resistance was high and delayed blue-staining. Thus further studies are needed to clarify the influence of weather conditions and host resistance on the development of blue-stain fungi associated with $T$ piniperda. 


\section{ACKNOWLEDGMENTS}

The study was carried out at the Norwegian Forest Research Institute (NISK), As, and the Swedish University of Agricultural Sciences (SLU), Garpenberg, and was supported by a grant from The Royal Academy of Forestry and Agriculture (KSLA) in Sweden. We thank C Hellqvist, SLU and O Olsen, NISK for technical assistance, E Christiansen, NISK for valuable discussions and comments on the manuscript, and François Lieutier, INRA, Orleans for translating our summary into French.

\section{REFERENCES}

Basham HG (1970) Wilt of loblolly pine inoculated with blue-stain fungi of the genus Ceratocystis. Phytopathology 60, 750-754

Bramble WC, Holst EC (1940) Fungi associated with Dendroctonus frontalis in killing shortleaf pines and their effect on conduction. Phytopathology 30, 881-899

Butin H (1963) Über Sclerophoma pityophila (Corda) $\vee$ Höhn als Bläuepilz an verarbeitetem Holz. Phytopathol Z 48, 298-305

Caird RW (1935) Physiology of pines infested with bark beetles. Bot Gaz 96, 709-733

Christiansen E (1985) Ceratocystis polonica inoculated in Norway spruce: blue-staining in relation to inoculum density, resinosis an tree growth. Eur J For Pathol 15, 160-167

Christiansen E, Horntvedt R (1983) Combined Ips/Ceratocystis attack on Norway spruce, and defensive mechanisms of the trees. $Z$ Angew Entomol 96, 110-118

Christiansen E, Solheim H (1990) The bark beetle-associated blue-stain fungus Ophiostoma polonicum can kill various spruces and Douglas fir. Eur J For Pathol 20, 436-446

Francke-Grosmann H (1967) Ectosymbiosis in wood-inhabiting insects. In: Symbiosis, Vol II. Associations of Invertebrates, Birds, Ruminants and Other Biota (Henry SM, ed) Academic Press, NY, 141-205

Grosmann H (1931) Beiträge zur Kenntnis der Lebensgemeinschaft zwischen Borkenkäfern und Pilzen. $Z$ Parasitenkd 3, 56-102
Hermanides-Nijhof EJ (1977) Aureobasidum and allied genera. Stud Mycol 15, 141-177

Horntvedt R (1988) Resistance of Picea abies to Ips typographus : tree response to monthly inoculations with Ophiostoma polonicum, a beetle transmitted blue-stain fungus. Scand $J$ For Res 3, 107-114

Horntvedt R, Christiansen E, Solheim $H$, Wang $S$ (1983) Artificial inoculation with lps typographus-associated blue-stain fungi can kill healthy Norway spruce trees. Medd Nor inst Skogforsk 38 (4), 1-20

Käärik A (1980) Fungi Causing Sap Stain in Wood. Swedish University of Agricultural Sciences, Dept of Forest Products Rep R 114, pp 112

Långström B, Hellqvist C (1988) Scots pine resistance against Tomicus piniperda as related to tree vitality and attack density. In: Integrated Control of Scolytid Bark Beettes (Payne TL, Saarenmaa H, eds) Proc IUFRO Working Party and XVII Int Congr Entomol Symp, Vancouver, BC, Canada, July 41988 , 121-133

Lieutier F, Yart A (1989) Preferenda thermiques des champignons associés à lps sexdentatus Boern et Tomicus piniperda L (Coleoptera: Scolytidae). Ann Sci For 46, 411-415

Lieutier F, Yart A, Garcia J, Poupinel B, Levieux $J(1988)$ Do fungi influence the establishment of bark beetles in Scots pine? In: Mechanisms of Woody Plant Defenses Against insects: Search for Pattern (Mattson WJ, Levieux J, Bernard-Dagan C, eds) Springer Verlag, NY, 321-334

Lieutier F, Yart A, Garcia J, Ham MC, Morelet M, LevieuX J (1989) Champignons phytopathogènes associés à deux coléoptères scolytidae du pin sylvestre (Pinus sylvestris $L$ ) et étude préliminaire de leur agressivité envers l'hôte. Ann Sci For 46, 201-216

Lieutier F, Yart A, Garcia J, Ham MC (1990) Cinétique de croissance des champignons associés à lps sexdentatus Boern et Tomicus piniperda L (Coleoptera : Scolytidae) et des réactions de défense des pins sylvestres ( $P$ inus sylvestris L) inoculés. Agronomie 10 , 243-256

MacCallum BD (1922) Some wood-staining fungi. Trans Br Mycol Soc 7 (4), 231-236 
Mathiesen A (1950) Über einige mit Borkenkăfern assoziierte Bläuepilze in Schweden. Oikos 2, 275-308

Mathiesen-Käărik A (1953) Eine Übersicht über die gewöhnlichsten mit Borkenkäfern assoziierten Bläuepilze in Schweden und einige für Schweden neue Bläuepilze. Medd Statens Skogsforskningsinst 43 (4), 1-74

Mathre DE (1964) Pathogenicity of Ceratocystis ips and Ceratocystis minor to Pinus ponderosa. Contrib Boyce Thompson Inst 22, 363388

Morelet M (1988) Observations sur trois Deutéromycètes inféodés aux pins. Ann Soc Sci Nat Archéol Toulon 40, 41-45

Nelson RM (1934) Effect of bluestain fungi on southern pines attacked by bark beetles. Phytopathol Z7, 327-353

Nelson RM, Beal JA (1929) Experiments with bluestain fungi in southern pines. Phytopathology 19, 1101-1106

Owen DR, Lindahl KQ Jr, Wood DL, Parmeter JR Jr (1987) Pathogenicity of fungi isolated from Dendroctonus valens, $D$ brevicomis and $D$ ponderosae to ponderosa pine seedlings. .Phytopathology 77, 631-636

Parmeter JR Jr, Slaughter GW, Mo-Mei Chen, Wood DL, Stubbs HA (1989) Single and mixed inoculations on ponderosa pine with fungal associates of Dendroctonus spp. Phytopathology $79,768-772$
Piou D, Lieutier F (1989) Observations symtomatologiques et rôles possibles d'Ophiostoma minus Hedgc (ascomycète : Ophiostomatales) et de Tomicus piniperda L (Coleoptera : Scolytidae) dans le dépérissement du pin sylvestre en forêt d'Orleans. Ann Sci For 46, 39-53

Rennerfelt E (1950) Über den Zusammenhang zwischen dem Verblauen des Holzes und den Insekten. Oikos 2, 120-137

Robak $\mathrm{H}$ (1932) Investigations regarding fungi in Norwegian ground-wood pulp and fungal infection at wood pulp mills. Nytt Mag Naturvidensk V 71, 185-330

Robak H (1952) Dothichiza pithyophila (Cda) Petr the pycnidial stage of a mycelium of the type Pullularia pullulans (de B) Berkhout. Sydowia Ser II 6, 361-362

Siemaszko W (1939) Zespoty grzybów towarzysacych kornikom. polskim (Fungi associated with bark-beetles in Poland). Planta Pol 7, 154

Solheim H (1988) Pathogenicity of some lps typographus-associated blue-stain fungi to Norway spruce. Medd Nor Inst Skogforsk 40 (14), 1-11

Upadhyay HP (1981) A monograph of Ceratocystis and Ceratocystiopsis. The University of Georgia Press, Athens GA, pp 176 